\title{
If All the World Were Listening
}

\section{Ann Jones}

Margaret played with two yellow leaves that had floated down upon her like toys dropped into a playpen by a smiling mother. Shadows of the picket fence in whose corner she sat, fell like bars across her. She watched them on her arm curiously, thinking of locks and keys and rooms with no windows. In front of her, on the huge rocks that rose like a miniature mountain in the middle of the yard, the moss had dried and turned brown. If she had felt like it, she could have filled a coffee can with water and pouring it over a section of the tight brown moss, watched it turn green before her eyes. But things were different today, and she didn't feel like it. She threw the two yellow leaves over the fence where they fell quietly on the wooden sidewalk. She watched them for a long time but they didn't even quiver.

Why didn't you go with them?

They didn't ask me.

Don't lie. She called you.

I was afraid I would cry.

You hid. They won't like that.

But I came back. I'm here now.

Stupid. Stupid. Stupid. You should have gone with them. Stupid to sit here. It's cold.

Not true. If she didn't move it wasn't so cold. The sun was full of the illusion of warmth, bouncing its rays off the shingled wall of the house, breaking into dancing, sparkling patterns of light under the mulberry trees where leaves kept falling. It was a beautiful day. She felt like screaming or biting herself to keep from making more words in her mind and spoiling what was around her. But at the same time she knew it was stupid to just sit here. There were goose bumps all up and down her arms because of the church bell that kept ringing and ringing. If she got up and walked off, maybe she could get far enough away so she wouldn't have to hear it anymore.

There was a noise in the house of her neighbor and she looked up. What it might be, she could not guess because as far as she knew, she was alone. Those who had cars had piled them to the ceiling with their belongings and driven off with cans strapped to their running boards and canvas bundles tied to the tops. 
Jimmy-John had been the only one of the car-people who had waved to her as they went by, but his mother had reached out and grabbed his little wrist, jerking it back in the car so hard that it must have hurt, and then she had rolled up the window against the dust and they were gone. Next came the people with horses and mules and wagons, and after them came the walkers. By then the street was like a thick river of stirred-up dust that still coated the trees and house fronts.

Peering through the pickets to the wooden sidewalk, Margaret saw that her two leaves had begun a gentle rocking movement as though they were singing to themselves. She watched them for awhile, feeling herself far away, and then suddenly she sat up in alarm, missing something that had been with her forever. Quickly she checked the hem of her dress where she kept her hidden treasure but it was still there, and she smiled in relief, gradually understanding that it was only the sound of the bell that she was missing. And this was understandable. After all a bell couldn't ring without someone to pull its rope.

Reverend Wright did this himself every Sunday, and for prayer meeting on Wednesday night, too. She had often watched him when he didn't know she was there and there was something cruel in the way he controlled the bell, his lips firm, his eyes like steel plates protecting what was inside. She hated him until the Wednesday evening, when crouching in the shadows near the organ, she had seen him raised to tip-toe by the bell rope, his black pants riding up his leg exposing a piece of hairless white skin and a bony ankle. The thought of him with no socks on, ringing the bell in the dark church had come down on her with such force that she rolled into a little ball behind the organ and spent the next ten minutes laughing and crying at the same time. You couldn't hate someone with ankles like that. Ever after she had not been afraid of Reverend Wright. And I am not afraid of him now, she thought. I am not afraid of anyone.

They had all been so solemn, especially the walkers with their little satchels or their cardboard suitcases or their duffel bags slung over their shoulders. Quite a few had pushed wheelbarrows loaded with things that kept falling out. A pot here, a dish there. No one bothered to pick them up. Right now, Mrs. Fordham's best china platter with the brightly painted turkey in its center and a wreath of acorns and oak leaves all around its rim, was laying to one side of the road, its colors dulled by layers of dust.

Usually these people didn't like to be watched but today, Margaret hadn't even bothered to hide while she looked at them because many of them had looked right at her without seeing her at all. Once she had recognized the sound of some squeaking wheels and standing up had looked directly at a boy pulling a little red wagon with three small tow-headed children in it. The boy was the same one who came down the street twice a week with a load of dirty laundry in a big wicker basket balanced on that same wagon. He almost stopped when he saw her, and she knew he was remembering sharing a handful of jelly beans with her just the other day, but his father, coming behind him, carrying a huge pack on his back, looked up just then and yelled at him to go on. Margaret had the feeling that if he had had a switch handy he would have used it on the boy as though he had been a balky horse or mule. 
For hours they had passed like this heading west across the featureless flat land like a line of ants that seemed to disappear finally into the furious red heart of the setting sun. Angry streaks of pink and luminous orange cut into the violet sky around them. There were no clouds. No sound except for the creaking noise of packs being shifted on sore shoulders, or tired feet slogging along through the fine dust, or an occasional sob as someone, usually one of the older people, stopped by Margaret's hiding place to lean on her fence and rest. At times like this, Margaret sat very still behind the pickets and looked at them closely. One old lady, her gray hair working loose from its coil on the back of her head, had put her hand up to a brooch made of auburn colored human hair that was pinned to her high-necked dress. Margaret could see her gaining strength from this contact before she went on. Her long blue dress had burrs stuck in its hem, and her soft kid shoes left pretty little patterns in the dust as she walked away. A middleaged man with thick sideburns and a heavy brown moustache was waiting for her, standing to one side of the passing walkers. He was pushing a wheelbarrow with a little brown armless rocking chair tied to the top of his load. When the old lady came up to him, he put an arm around her shoulder and they stood there for a moment watching the silent people passing by, and then they went on. Maybe I should have gone with them, Margaret thought now. I wonder where they are. But even their tracks had disappeared in the running river of dust and there was no following.

It was right after that when the walkers had begun to run, and later some of them had abandoned their bundles and carts and gone on without them. Out on the flat land, Margaret could see clumps of dark objects scattered here and there like shrubbery magically grown in the night. Curious, she had gone into the road in front of her own house to look more closely at their discarded belongings and even now she found herself shivering at the thought of what they had been carrying with them, not all of which had been left behind. Why had they thought these particular things were so important? Didn't they guess that, even if they had been planning to give it away, no one would have wanted that obscene kind of charity? Who would want it? Why? Margaret herself wouldn't, although everything she had ever owned came first from one of them. She shuddered. What was so important about them? The loose lips of Fred Cobbel, the watery eyes of Catherine Summers, the ragged odds and ends of everything folded neatly and thrust into your arms, which of course would be empty because you couldn't always think of everything, and anyway, they might hurt you if you didn't take what they were offering. Margaret always took what they were offering, although sometimes they were hardly out of sight before she got sick.

Whatever had fallen in the house next door went rolling across the floor which slanted like the deck of a ship and had been the chief cause of Mrs. Raskell's broken ribs. The day it had happened, Mrs. Raskell had finished the last of the pink wine and stood up, one hand on the kitchen table, but when she had started to move, her feet had gotten away from her, and in a mad dance she had gone crashing into the drainboard of the sink. It had been a little sad at first to see her moving stiffly around with gray tape showing under the tight red sweater.

Oh, remember how it felt? 
The golden feeling. The warmth. Everything pushed away from you.

But it is gone now.

And so is he.

The man who had been visiting Mrs. Raskell had shouted and pounded his fists against the kitchen wall after the accident and then he had left. The other man, half of his face covered by a thick red beard, had arrived the next day, the book he was carrying almost disappearing in one huge rough hand. He had come as far as the porch and hearing the miserable crying of the woman inside had paused. He turned, and seeing Margaret sitting in her place behind the broken pickets, had taken his pack off his back and dropped it to his feet, talking all the while in her direction. "Sweet Jesus," he had said, "why do I come here?"

I think I smiled then, Margaret thought now. They were such soft words. I know I leaned over to finish drying my hair which I had just washed. The weather had been warm. She remembered how it felt to be warm and how, during the rest of that afternoon, the sun had fallen on the liquid in the green bottle between his legs, reflecting onto the pages of the book he had read to her. It was a small book. With very few words. He turned over the last page and put it down. "I wrote that book," he said. "I'm a poet. If all the world were listening-"

She ran her fingers through his beard trying to find the hard bones of his jaw and chin. "Poet, poet," she whispered.

He looked at her for a long while. "Someday I'm going to find a woman I don't need and I'll stay with her forever." Turning her around, he pulled her back against him, hiding his face in her long dark hair.

"Do you need me?" she asked.

"Sweet Jesus," he said, "of course I do."

Later, Mrs. Raskell had come out on her porch and stood there looking up and down the long street, but the man had motioned for Margaret to be quiet and stay with him inside the deep shadows. Putting her hand up to shield her eyes from the sun, Mrs. Raskell had looked for a long time in their direction and Margaret had started to giggle, falling on her back and staring at the sky flickering between the green leaves of the mulberry tree. And then she had felt his hand on her mouth and then his lips had replaced his hand and they had begun all over again while Mrs. Raskell had gone into her house alone and played her phonograph, making a stream of loud sound like dirty dish water flung out of an open window.

It was finally cold. Whatever had fallen and rolled across the floor in Mrs. Raskell's house was now quiet.

Cheap. Cheap. You cheap little son of a bitch.

Those are not $m y$ words.

They are what she called you.

Margaret remembered how Mrs. Raskell had stood screaming down at her over the picket fence, her wild yellow hair matted to her head as though she hadn't even run her fingers through it since getting out of bed that morning. Every once in awhile she would stop yelling and just stand there glaring down at 
Margaret, holding her folded arms against her sides, breathing stiffly in and out, in and out. Margaret had never paid any attention to the way people breathed until then. It was just something you did to stay alive, but it must have hurt Mrs. Raskell dreadfully. She found herself breathing slower and deeper while she looked up at the older woman. It was almost like singing with her in the church choir to breathe in at the same time as she did, then slowly out.

"Sneaking around in corners like this . . . . watching everything I do, everyone who comes to my house. What do you think you are doing, you little bitch?"

Margaret didn't answer, and Mrs. Raskell, as though frozen to the spot, had stood there a moment more before sinking slowly to her knees and looking through the pickets at her. "Margaret, Margaret. Wasn't he lovely though? Wasn't he the most beautiful man you have ever seen? But of course how could you tell? What a waste! It takes someone like me to know about someone like him." She laughed.

There were lines spreading out from the corners of her eyes and dropping down from the corners of her lips; and starting up from the base of her neck, ringlets of lines in the coarsening skin. Margaret paid more attention to these, than to the words. Looking into Mrs. Raskell's eyes was like looking into a field of soft blue flowers. She had to look away finally, drawing patterns in the dust with the tip of her finger, then holding two fingers together stiffly, drawing the same pattern double. It had been Mrs. Raskell who, sighing deeply, had stood up first and gone into her house leaving Margaret sitting alone.

The day rocked back and forth around Margaret now. She could not find her place in it. The sky was wrong, the movement of the trees, the little shifts in memory. Where was Mrs. Raskell right now? She would not have been able to walk very far or run with those broken ribs. Maybe she was among those dark objects out on the plain.

I wouldn't hurt her.

She said you did.

Sweet Jesus, I wouldn't hurt anyone.

She looked up from herself and saw in the distance where the city lights should have come on, flames that were taller than the tallest buildings must have been.

What is happening now?

Burning.

Is that why they were running?

Certainly. The poet is burning their houses.

She huddled against this sudden new cold, pulling her bare feet under the cloth of the red dress, thinking of the things she could have brought with her if she had gone with the others. I could have brought my box, she thought, with the cinnamon that Mrs. Cobbel was going to use in her baking, or the thread that Mrs. Brian had thought she dropped from her big leather handbag, or the keys to Manny's car. The car was still in the back of the house. It made her sad to see it. Poor Mrs. Raskell. Manny's wife had hated her from the beginning, even when she had been so sick with her broken ribs she had hated her.

"What keeps her alive?" she had asked her husband. 
"Medicine," he said laughing.

"Yes," she said bitterly, "and I wish I had some of it."

"You," he screamed. "You tired old bitch, you're too old for that kind of medicine."

And one of them had slapped the other and they both had begun to yell and Margaret, shaking because of Mrs. Raskell, had slipped over to the car and taken the keys to put into her box.

She thought now of how Manny had loaded the car with everything in the house including the new golden-oak ice box and how his wife had stood there not saying anything even when he put a jumbled pile of clothes in the place in the car where she usually rode. When this happened, she sat down on one of the white-washed boulders marking the corner of the vegetable garden and wrapped her arms in her kitchen apron. Manny slid behind the wheel and tried to start the car. He got out and searched wildly through all his pockets while his wife looked on interestedly. Finally, his face had turned as purple as the sky was and he had reached under the hood and yanked loose a bunch of wires. "No other god-damn person is going to use this car if I can't," he had shouted, and gone running down the road carrying his last order from the mail-order house still in its cardboard shipping box because he hadn't had time to open it. "It's a poor man's game now, too," he had cried. "Try and stop me! Just try!"

His wife hadn't tried. She had stayed in the yard for awhile and then begun calling and calling, until even she realized that no one was going to answer her, certainly not Margaret, or the cat, or the little banty hen hiding in the barn with them. When she had left, she had gone slowly, not carrying anything, looking back over her shoulder twice.

Margaret watched the sky which really did look strange. Such a silence as this had never happened to her before. She sat in it like a goldfish in a bowl, feeling herself swimming in slow circles through sun-speckled water, in and out of the waving fronds of water weeds. She felt someone near her, looking down on her, about to shake little flakes of goldfish food into her bowl, and when she looked up, she had to smile because the women she saw was no stranger.

Always before, weeds, touched by the bottom of the basket the woman carried, had betrayed her coming with their dry rattle, or her feet, pressing down on the dust-covered planks had squeaked a little. This was the first time she had surprised Margaret like this. She was tall and pleasing to look at. The golden crown of braid fastened to the top of her head threw out red sparks as she stood there in the fading light. She smelled like a store full of bath powder and lavender soap. Her blue velvet dress had a rich trimming of dust lining its folds. Reaching in her basket, she drew out a paper and holding it for a moment in full sight, dropped it right in front of Margaret's hiding place.

Margaret could hear its crispness singing back and forth in the arc of its falling. It settled on the board sidewalk, rocking for a second beside the two golden leaves. This was the fifth time this had happened and she looked at it fearfully, feeling the first four crackle in the hem of her dress. She had been so afraid that people would find out that she had them and kill her for them. She had almost 
thrown the first one into the outhouse behind Hall's store because it had threatened her with its rattling. And then she had learned how to fold them lengthwise and with a needle from Manny's wife and the thread from Mrs. Brian had sewn it into the hem of her dress.

She jumped up and ran out to the sidewalk to pick up this new one. By now, the woman was a quiet shadow moving down the street away from her, away from the plains and the people, back toward the clouds of smoke obscuring the city. Margaret almost called out to her to stop, to wait. But just then a cock pheasant made a long scream of gold, cleaving the silence like a sharp axe splitting a log. Both Margaret and the woman stopped and looked at each other across the distance separating them. And then the siren on the top of the volunteer fire department rose to its highest pitch, screaming a waveless tone that hung in the air like a threat, and right at their feet, between the two of them, a long plank of the sidewalk split down its center. Margaret turned and ran back into the yard, hiding in her fence corner, clutching the paper with the beautiful words she could not read. His voice had been a series of ocean waves, peaking, breaking, receding, building over and over. What had the poet told her? Why had he wanted to burn their houses? She looked up at her own house in alarm.

The siren stopped. The pheasant did not call again. When the new sound came it fell with a terrible ripping noise that rolled her right down on the ground hugging herself in terror. It slammed against the house, and a window in the back broke with a foolish tinkle. Then it was over. The small dust she had created in her falling rose like steam around her and then it too, was gone. She stood up, shaking herself. The cat, hidden in the vines at the corner of the porch, moaned loudly.

"Come here, you baby," she called, but he ran away from the sound of her voice. Lifting the hem of her dress, she counted the sewn-in pages once again and without looking behind her, pushed the broken gate aside and went on down the planks. Near the last of the houses, she found one more page of the poet's book nailed to the fence. She picked it up and walked on with it in her hand. Two crows landed almost at her feet. She watched their yellow eyes and the luminous shine of their feathers as they began to pick among the dropped bundles. She thought of Fred Cobbel and Reverend Wright. She thought of Manny's wife and Mrs. Raskell. She thought of the strange objects on the darkening plain, the angry furnace of the setting sun, the brooch made of fading auburn hair. Soft ashes fell on her cheeks and she wiped them off with the back of her hand. Ahead of her a low line of flickering fire-hearts divided the purpling sky from the blue-black earth whose streaked shadows seemed to be racing across the frozen fields to engulf her. She walked into them steadily, the poet's words rustling in her hem, the crows, tipping their bodies between slanted wings, flying along with her.

The End 